\title{
Pendampingan Belajar Blended Learning dengan Model Flipped Classroom Dimasa Pandemi Untuk Siswa Sekolah Dasar
}

\author{
Siwi Utaminingtyas ${ }^{1}$, Atika Dwi Evitasari² \\ ${ }^{1}$ Program Studi Pendidikan Guru Sekolah Dasar, Fakultas Ilmu Pendidikan IKIP PGRI Wates \\ ${ }^{2}$ Program Studi Pendidikan Guru Sekolah Dasar, Fakultas Ilmu Pendidikan IKIP PGRI Wates \\ Corresponding email: siwiutami66@gmail.com
}

\begin{abstract}
The world is currently facing a global problem that must be faced together, namely the COVID-19 pandemic. Activities and learning processes are packaged online (online) from elementary school to university level. Changes in the delivery of online learning lead to various problems, such as internet limitations, the lack of availability of cellphones/computers, and the biggest problem is that learning materials are not delivered to students as a whole. For this reason, we support the Government's efforts to always seek and find solutions so that learning activities can take place well during the pandemic, namely by carrying out community service activities, specifically for elementary school students, by combining online learning with face-to-face which is called the Blended Learning model. flipped classroom. Our service is carried out in stages through lecture, modeling, question and answer, discussion, and practice methods. The teachers are actively involved in discussions, practice learning management methods using the blended learning model of the flipped classroom and apply them in the classroom. Based on the results of interviews and observations in virtual classrooms, there is a clear difference before applying the blended learning model. Learners are more motivated in learning; students are more flexible in studying a learning material independently; avoiding misunderstandings in understanding the learning material, because at the end of the lesson/reflection the teacher and students conduct virtual face-to-face discussions to discuss the learning material more deeply.
\end{abstract}

Keywords: Blanded Learning; Flipped Classroom; elemantary school students

\begin{abstract}
ABSTRAK
Saat ini dunia tengah menghadapi masalah global yang harus dihadapi bersama, yaitu pandemi covid-19. Kegiatan dan proses pembelajaran dikemas secara online (daring) dari tingkat sekolah dasar hingga perguruan tinggi. Perubahan penyampaian pembelajaran secara daring menyebabkan munculnya berbagai permasalahan, misalnya keterbatasan internet, kurang tersedianya HP/ komputer, dan masalah terbesarnya adalah tidak tersampainya materi


pembelajaran ke peserta didik secara utuh. Untuk itu, kami mendukung upaya Pemerintah yang selalu mengupayakan dan mencari solusi agar kegiatan pembelajaran dapat berlangsung dengan baik selama pandemi, yaitu dengan melakukan kegiatan pengabdian pada masyarakat, tepatnya pada siswa Sekolah Dasar, dengan memadukan pembelajaran daring dengan tatap muka yang disebut dengan Blended Learning model flipped classroom. Pengabdian kami laksanakan secara bertahap melalui metode ceramah, pemodelan, tanya jawab, diskusi, dan praktik. Bapak Ibu guru terlibat aktif dalam diskusi, mempraktekkan cara pengelolaan pembelajaran dengan blanded learning model flipped classroom dan menerapkan di kelas. Berdasarkan hasil wawancara dan pengamatan di kelas secara tatap maya, terlihat sekali perbedaan sebelum menerapkan model blanded learning. Peserta didik lebih termotivasi dalam belajar; peserta didik lebih leluasa dalam mengkaji sebuah materi pembelajaran secara mandiri; terhindarnya salah persepsi dalam memahami materi pembelajaran, karena di bagian akhir pembelajaran/ refleksi guru dan peserta didik melakukan diskusi secara tatap maya untuk membahas materi pembelajaran lebih dalam.

Kata kunci: Blanded Learning; Flipped Classroom; Siswa Sekolah Dasar

\section{PENDAHULUAN}

Pandemi Covid-19 berdampak pada berhentinya beberapa kegiatan di seluruh sektor, hal ini disebabkan karena penyebaran virus yang belum mereda. Dunia Pendidikan juga terkena imbas dan dampaknya. Proses pembelajaran yang semula dilaksanakan di dalam kelas berganti menjadi pembelajaran dalam jaringan (daring) dikarenakan kondisi pandemi saat ini. Pembelajaran daring dijadikan sebagai salah satu alternatif dalam memecahkan permasalahan pendidikan di Indonesia terutama selama Pandemi Covid 19. Hal ini sejalan dengan kebijakan Pemerintah, bahwa selama pandemi pembelajaran dikemas dan disampaikan secara daring (online), hal ini disebabkan karena interaksi antara guru dan peserta didik yang dilaksanakan secara tatap muka dikhawatirkan dapat menjadi media penularan covid lebih mudah dan cepat. (Surat edaran nomor 15 tahun 2020)

Menurut Handarini dan Wulandari (2020) pembelajaran daring adalah pembelajaran yang dikemas tanpa bertatap muka langsung, namun menggunakan platform yang dapat membantu proses pembelajaran. Pembelajaran daring menggunakan teknologi internet dan dapat dilakukan dengan beberapa media, baik media cetak seperti modul maupun non cetak (audio dan video). Guru dapat menggunakan Whatsapp, Google Classroom, 
Zoom, atau aplikasi lainnya. Tentunya dalam penerapan daring di kelas yang terbilang baru bagi guru dan peserta didik banyak sekali ditemukan kendala dan kesulitan di semua jenjang pendidikan, terutama di tingkat Sekolah Dasar.

Peserta didik di bangku Sekolah Dasar belum terbiasa dengan pembelajaran yang dikemas secara online dan peserta didik dituntut belajar secara mandiri. Kemandirian peserta didik dalam belajar menjadikan pembelajaran berpusat pada peserta didik (student centered), inilah yang menjadi kendala pelaksanaan daring di Sekolah Dasar. Student Centered dengan karakter peserta didik sekolah dasar yang masih membutuhkan pendampingan dalam belajar tentunya kurang efektif jika diterapkan. Selain itu, ada beberapa kendala yang dihadapi selama proses pembelajaran, seperti keterbatasan fasilitas pendukung seperti HP, kuota, jaringan internet, dan kurangnya waktu orangtua dalam mendampingi belajar anak.

Untuk mengatasi berbagai kendala dan permasalahan di atas, Pemerintah selalu mengupayakan dan mencari solusi agar kegiatan pembelajaran dapat berlangsung dengan baik. Salah satunya dengan memadukan pembelajaran daring dengan tatap muka yang disebut dengan Blended Learning. Wardani, Toenlioe, dan Wedi (2018) menyatakan bahwa Blended Learning adalah sebuah metode pembelajaran yang dikemas dengan menggabungkan antara pembelajaran tatap muka (face to face) dengan $e$ learning. Bonk dan Graham (2006) menyatakan bahwa Blended Learning merupakan suatu kombinasi dari dua instruksi sistem pembelajaran yaitu sistem pembelajaran tradisional dan sistem pembelajaran dengan menekankan pada peran dan fungsi teknologi komputer. Jadi dapat disimpulkan bahwa Blended Learning adalah sebuah strategi belajar mengajar dengan memadukan pembelajaran berbasis tatap muka dengan pembelajaran berbasis teknologi untuk pencapaian tujuan pembelajaran.

Oktaria (2018) menyatakan bahwa Blended learning memiliki beberapa macam model, antara lain rotation model, flex model, self-blende model, enrichead-virtual model. Semetara itu, rotation model memiliki beberapa model yaitu station-rotation model, lab-rotation model, flipped classroom model, dan individual-rotation model. Pembelajaran daring harus 
tetap mengaktifkan peserta didiknya, untuk itu dari sekian model blended learning yang cocok untuk lebih mengaktifkan peserta didik dimasa pandemi dengan pembelajaran secara daring, yaitu penggunaan blended learning model flipped classroom. Hal ini sejalan dengan pendapat Muzyka \& Luker (2016: 3) memaparkan bahwa di dalam flipped classroom terdapat komponen yang sangat penting, yaitu active learning. Brent (2013) mengungkapkan bahwa flipped classroom merupakan strategi yang dapat diberikan oleh pendidik dengan cara meminimalkan intruksi langsung dalam pembelajaran, namun memaksimalkan interaksi antar peserta didik dengan memanfaatkan teknologi untuk mendukung materi pembelajaran yang diakses secara online.

Melihat kendala-kendala yang telah terjadi di atas, maka untuk mendukung program Pemerintah perlu adanya peran dari pihak lain dalam membantu keterlaksanaan proses pembelajaran selama pandemi covid-19 terutama di sekolah dasar. Oleh karena itu, mahasiswa mahasiswi bersama Dosen PGSD IKIP PGRI Wates menjalankan program pendampingan belajar berbasis Blended Learning dengan model Flipped Classroom untuk membantu peserta didik di tingkat sekolah dasar. Kegiatan ini merupakan implementasi dari Tridharma Perguruan Tinggi di bidang pendidikan dan pengajaran, dan sebagai sarana mengaplikasikan keterampilan mahasiswa untuk menerapkan ilmu yang pernah di dapat di bangku perkuliahan. Melihat keterkaitan dan latar belakang di atas, maka penulis melaksanakan kegiatan pengabdian pada masyarakat yang berjudul "Pendampingan Belajar Blended Learning dengan Model Flipped Classroom Dimasa Pandemi Untuk Siswa Sekolah Dasar"

\section{TINJAUAN PUSTAKA}

\section{Pengertian Blended Learning}

Pemanfaatan Teknologi Informasi dalam pendidikan dan pembelajaran sebagai salah satu alternatif di masa pandemi, tentunya membawa perubahan cara mengajar dan kegiatan belajar, dari pembelajaran yang bersifat konvensional atau tatap muka berubah menjadi pembelajaran berbasis digital/ online. Namun pembelajaran online memiliki berbagai kendala, salah satunya 
adalah tidak adanya feedback secara langsung antara pendidik dengan peserta didik, dalam hal penyampaian materi kurang memuaskan karena tidak ada interaksi secara langsung. Untuk itu, diperlukan solusi mengatasi kelemahankelemahan pembelajaran secara online, yaitu dengan memadukan tatap muka/ pembelajaran berbasis kelas dan pembelajaran yang dikemas secara daring (online).

Blended berarti campuran dan learning berarti pembelajaran. Bielawski dan Metcalf (Husamah, 2014: 16) menyatakan bahwa Blended Learning merupakan suatu konsep pembelajaran yang baru dimana penyampaian materi pembelajaran dapat dilaksanakan secara online maupun di kelas. Staker (Widiara, 2018: 50) mengungkapkan bahwa Blended Learning adalah salah satu program pendidikan formal dimana memungkinkan peserta didik belajar dengan dua cara yaitu sebagian melalui konten dan petunjuk secara online (daring) dengan kendali mandiri terhadap waktu, tempat, maupun kecepatan belajar. Abdullah (2018), menyatakan bahwa ada beberapa unsur blended learning antara lain :

a. Tatap muka di kelas

b. Belajar secara mandiri

c. Menggunakan aplikasi (web)

d. Tutorial

e. Mengembangkan kerjasama

f. evaluasi

Dari pendapat ahli di atas, dapat digaris bawahi bahwa blended learning sebuah strategi belajar yang memadukan pembelajaran berbasis kelas atau tatap muka dengan pembelajaran berbasis teknologi dan informasi secara daring (online). 


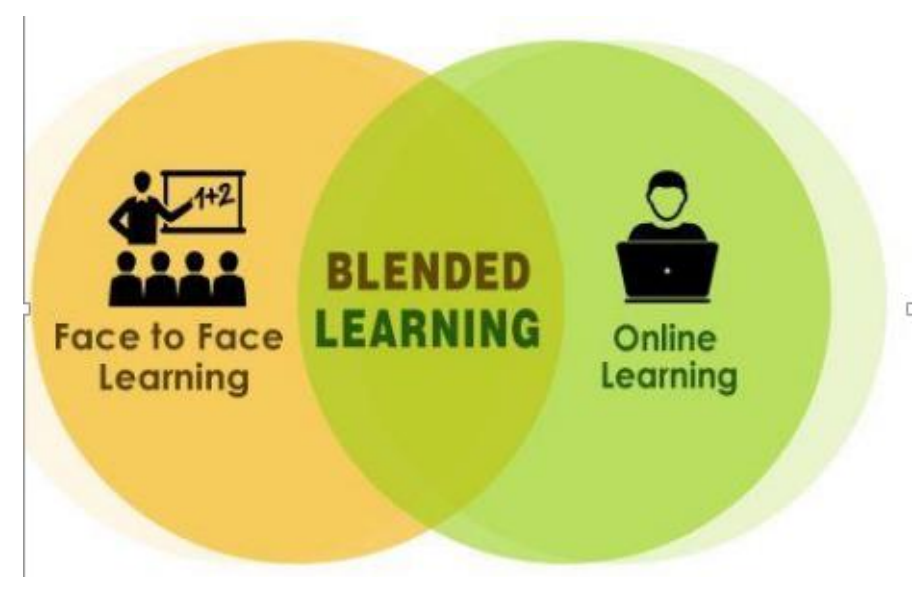

Ilustrasi Pembelajaran Menggunakan Blended Learning

\section{Karakteristik Blended Learning}

Secara umum, blended learning memiliki tiga makna antara lain: 1) perpaduan/integrasi pembelajaran tradisional dengan pendekatan berbasis web on-line; 2) kombinasi media dan peralatan (misalnya buku teks) yang digunakan dalam lingkungan e-learning, dan 3) kombinasi dari sejumlah pendekatan belajar-mengajar terlepas dari teknologi yang digunakan, Sukarno (2011: 2).

Chaeruman (2017) menyatakan bahwa Blended learning pada dasarnya mengkombinasikan aspek positif yaitu memadukan dua lingkungan belajar, yaitu pembelajaran di kelas dan e-learning. Ada dua jenis pembelajaran daring (online) yaitu :

a. Sinkronus

Pembelajaran daring sinkron adalah pembelajaran menggunakan komputer atau HP sebagai media yang terjadi secara serempak, waktu nyata (realtime). Contoh text chat dan video chat.

b. Asinkronus

Pembelajaran yang berpusat pada siswa mirip dengan belajar mandiri menggunakan sumber belajar online yang diperlukan.

Kombinasi positif antara pengemasan pembelajaran dengan sinkronus dan asinkronus, menciptakan pengalaman belajar yang menyenangkan dan menciptakan proses pembelajaran yang hidup walaupun dilaksanakan secara online, hal ini sependapat dengan penelitian Dziuban (2018) dan 
Kalantarrashidi (2015), penerapan blended learning memberikan pengalaman belajar yang tinggi kepada peserta didik sehingga meningkatkan hasil belajar, dan membuat kepuasan belajar peserta didik lebih tinggi dibandingkan dengan pembelajaran konvensional.

Driscoll (2012) menyatakan bahwa ada 4 konsep tentang blended learning yaitu

a. Pembelajaran menggunakan blended learning mengkombinasikan teknologi berbasis web.

b. Blended learning merupakan penggabungan dari berbagai penerapan teori belajar behaviorisme, konstruktivisme, dan kognitivisme.

c. Blended learning merupakan kombinasi berbagai macam teknologi seperti penggunaan video, film, CD-ROM dengan pembelajaran tatap muka.

d. Blended learning menggabungkan berbagai teknologi pembelajaran dengan penugasan yang aktual sehingga menciptakan pengaruh yang baik dan positif dalam pembelajaran.

Blended learning menempatkan peran pendidik dan orang tua secara imbang, pendidik sebagai fasilitator dan mediator, pendidik memberikan arahan menggunakan aplikasi yang digunakan, dan menjelaskan materi pembelajaran secara terstruktur, sedangkan orangtua sebagai pendukung. Blended learning sebagai suatu solusi mengatasi kelemahan-kelemahan pembelajaran secara online (daring), karena menggabungkan antara pembelajaran online, offline dan tatap muka.

\section{Implementasi Blended Learning dengan Model Flipped Classroom}

Flipped Classroom lebih dikenal dengan pembelajaran terbalik, yaitu suatu konsep pembelajaran yang diskema dengan cara peserta didik diperkenalkan dengan konsep yang sudah dipersiapkan oleh guru (video, internet, perekaman audio-visual), setelah peserta didik menyaksikan materi pembelajaran, peserta didik berdiskusi, menyelesaikan tugas, memperluas konsep yang dipelajari dari buku dan internet, Bergmann \& Sams (2012); Saunders (2014). Pendapat tersebut sejalan dengan Yulietri \& Mulyoto (2015) Flipped Classroom merupakan suatu model dalam Blended Learning 
yang kegiatan belajarnya dimulai dengan peserta didik mempelajari materi pembelajaran di rumah dimana materi pembelajaran sudah dishare oleh guru, kemudian mengerjakan tugas saling berdiskusi, dan diakhir guru memberikan penguatan atau materi.

Blended learning dengan model Flipped Classroom pada hakikatnya merupakan pembelajaran dengan berpusat pada peserta didik, dengan sistem membalik kelas maka peserta didik tidak akan menghabiskan waktu dalam belajar dengan mendengarkan ceramah dalam forum kelas secara online, namun akan lebih banyak memberikan waktu kepada peserta didik untuk mengeksplor materi pembelajaran yang sudah dishare oleh guru sebelumnya. Peserta didik memperluas konsep materi pembelajaran, mengeksplor pengetahuan di luar kelas, memecahkan masalah baik secara individu ataupun kelompok. Sementara itu di akhir pembelajaran, guru menjelaskan materi dengan memberikan penguatan kepada peserta didik. Ada 3 peran guru dalam model pembelajaran ini, yaitu :

a. Menciptakan pembelajaran yang aktif dengan memberikan kesempatan kepada peserta didik untuk belajar mandiri

b. Menjadi fasilitator

c. Merencanakan kegiatan tindak lanjut

Untuk lebih jelasnya langkah-langkah pembelajaran Blended learning dengan model Flipped Classroom adalah sebagai berikut :

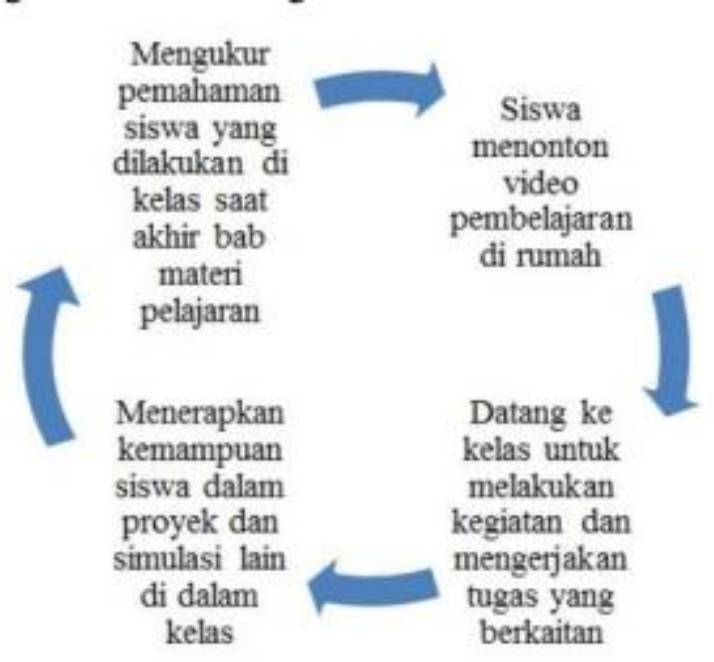


Gambar 1. Langkah-langkah Pembelajaran Flipped Classroom, Steele

Dari gambar langkah pembelajaran di atas blended learning model flipped classroom menganut model pembelajaran PEDATI (Pelajari, Dalami, Terapkan, dan Evaluasi), Chaeruman (2017), dimana untuk langkah pertama dalam pembelajaran Flipped Classroom adalah peserta didik mempersiapkan diri untuk mengikuti pembelajaran di rumah, peserta didik menonton video yang dipersiapkan oleh guru. Langkah kedua peserta didik mengikuti kelas secara online mengerjakan tugas dari guru berkaitan dengan materi pembelajaran. Langkah ketiga, peserta didik mampu menerapkan materi pembelajaran yang diperoleh dalam proyek ataupun simulasi yang dipandu dengan menggunakan LKPD (lembar kerja peserta didik). Langkah ke empat, guru melakukan diskusi, mengukur pemahaman peserta didik melalui kuis, dan memberikan penguatan di akhir pembelajaran.

\section{Kelebihan dan Kekurangan Blended Learning Model Flipped Classroom}

Penerapan blended learning dalam pembelajaran di kelas tentunya memiliki suatu kelebihan dan kelemahan. Adapun kelebihan dari Blended learning itu sendiri antara lain :

a. Peserta didik dengan bimbingan guru lebih leluasa mempelajari materi pelajaran secara mandiri dengan memanfaatkan materi-materi pembelajaran yang disampaikan secara online.

b. Mempunyai kesempatan untuk berdiskusi, kolaborasi dan berdialog dengan teman dan pendidik melalui teknologi, tidak harus dilakukan secara tatap muka.

c. Guru dapat menambah materi pengayaan melalui fasilitas internet

e. Guru dapat meminta peserta didik membaca materi atau mengerjakan tes sebelum pembelajaran.

Sementara itu, kelemahan blended learning, antara lain:

a. Membutuhkan persiapan (perencanaan) dan waktu yang lebih matang, terutama dalam pembuatan video.

b. Sulit diterapkan jika sarana dan prasarana tidak mendukung (kuota, HP, jaringan) 
c. Jika guru tidak mampu berinteraksi dengan peserta didik secara aktif secara online, maka dapat mempengaruhi motivasi peserta didik dalam belajar.

d. Bagi peserta didik yang terbiasa dengan pengemasan pembelajaran secara tradisional/ konvensional memungkinkan peserta didik mengalami kesulitan dalam membiasakan diri dengan strategi belajar yang baru.

\section{METODE PELAKSANAAN}

Kegiatan Pengabdian Masyarakat ini dilaksanakan di SD Negeri Margosari, SD Negeri Jurangjero, dan SD Negeri Kalipetir 3, Kabupaten Kulon Progo, Yogyakarta. Pelaksanaan pengabdian masyarakat dilaksanakan pada bulan April sampai dengan Juni 2021. Sasaran pengabdian ini adalah siswa sekolah dasar, dengan memberikan pembekalan dan pelatihan kepada Bapak Ibu Guru Sekolah Dasar dalam mengatasi kendala-kendala pembelajaran yang dilaksanakan secara pandemi, yaitu dengan memberikan pelatihan dan pendampingan proses pembelajaran dengan model blanded learning model flipped classroom. Kegiatan pengabdian dibantu oleh mahasiswa mahasiswi PGSD IKIP PGRI Wates. Metode kegiatan yang dilaksanakan adalah ceramah, pemodelan, tanya jawab, diskusi, dan praktik.

\section{Ceramah}

Ceramah merupakan kegiatan menyampaikan materi secara lisan oleh pemateri. Pada sesi ini pemateri menggali permasalahan-permasalahan yang muncul selama pembelajaran online masa pandemi, kendala-kendala seperti apa yang sering dijumpai disaat mengelola pembelajaran kepada guru, serta menyampaikan materi tentang ruang lingkup pembelajaran daring/ online, blended learning, karakteristik Flipped classroom.

\section{Pemodelan}

Metode ini, digunakan oleh pemateri untuk memberikan contoh pelaksanaan pembelajaran dengan blended learning model flipped calssroom, baik dari persiapan pembuatan materi pembelajaran maupun pada saat proses pembelajaran dengan blended learning. Kegiatan ini 
diikuti oleh bapak ibu guru beserta mahasiswa mahasiswi PGSD IKIP PGRI Wates.

\section{Diskusi dan Tanya Jawab}

Diskusi dan tanya jawab merupakan suatu metode yang memberikan kesempatan kepada peserta untuk mengajukan pertanyaan kepada pemateri terkait materi yang disampaikan. Pada sesi ini, pemateri menjawab pertanyaan yang diajukan oleh peserta pelatihan.

\section{Latihan}

Kegiatan latihan ini dilaksanakan setelah dilaksanakan diskusi dan proses tanya jawab, pada tahap ini guru kelas berkolaborasi dengan mahasiswa mahasiswi PGSD. Jadwal pelaksanaan latihan di setiap SD berbeda beda, sudah dikonsultasikan kepada pihak sekolah. Pada pertemuan pertama yaitu guru bersama mahasiswa mahasiswi diberi tugas untuk mendesain dan mengembangkan pembelajaran dengan blended learning model flipped classroom. Pada pertemuan kedua mempresentasikan hasil pengembangan pembelajaran, baik materi pembelajaran maupun video pembelajaran. Pertemuan 3 diisi dengan praktek pembelajaran secara online dengan blended learning model flipped classroom di kelas. Kegiatan ini memanfaatkan media Whatsap untuk pembukaan pembelajaran, share materi ataupun video pembelajaran, dan google meet untuk merefleksi pembelajaran.

\section{HASIL DAN PEMBAHASAN}

Saat ini Indonesia dan dunia tengah dilanda pandemi Covid-19, dimana pandemi ini berdampak bagi seluruh aspek kehidupan masyarakat terutama dalam bidang pendidikan. Pandemi Covid-19 ini mengharuskan kita untuk tetap dirumah saja sehingga kegiatan pendidikan menjadi terhambat. Berdasarkan surat edaran No 4 Tahun 2020 tentang pelaksanaan kebijakan Pendidikan dalam masa darurat penyebaran corona virus disease (covid-19) dijelaskan bahwa proses pembelajaran dilaksanakan dari rumah melalui pembelajaran daring/jarak jauh mulai dari tingkat Sekolah Dasar hingga Perguruan Tinggi. Untuk sistem 
pembelajaran secara online (daring), peserta didik dan orang tua dapat memanfaatkan beberapa aplikasi, seperti Whatsapp, Zoom Meeting, Classroom, Google Meet, dan lain sebagainya. Hal tersebut memicu banyak permasalahan, misalnya keterbatasan internet untuk mengakses pembelajaran, kurang tersedianya HP /Komputer yang memadai, tidak tersampainya materi pembelajaran kepada peserta didik, kurangnya pengawasan dari orang tua, dan lain sebagainya.

Berdasarkan hasil wawancara dengan Bapak Ibu guru, dari pihak guru menyatakan bahwa terdapat tugas berat di pundak Bapak ibu guru, karena pembelajaran dari rumah melalui media daring (online) tentunya bukanlah hal yang mudah. Bagi bapak ibu guru yang terbiasa melaksanakan kegiatan pembelajaran secara tatap muka, keadaan seperti ini memunculkan berbagai kendala seperti ketidaksiapan proses pembelajaran. Hal ini sebagai dampak penyebaran Covid-19 yang terjadi secara cepat, membuat bapak ibu guru harus paham akan teknologi, karena melalui teknologi inilah salah satu penghubung bagi guru dan peserta didik melakukan pembelajaran tanpa harus melakukan pembelajaran tatap muka.

Pembelajaran online mengarah pada pembelajaran student centered, sehingga tanggung jawab dan kemandirian belajar dalam diri peserta didik tetap terlihat dalam proses pembelajaran. Namun muncul permasalahan baru dalam pembelajaran yang dikemas secara online, yaitu ketidakpuasan peserta didik dalam memahami materi pembelajaran, materi pembelajaran susah diterima oleh peserta didik. Saat pembelajaran, guru hanya menyampaikan penugasan dan capaian pembelajaran yang akan dipelajari di hari itu, memberikan penugasan kemudian tugas dikumpulkan sesuai kesepakatan. Tanpa adanya konfirmasi/ refleksi secara lisan di akhir pembelajaran, seharusnya guru tetap merefleksi pembelajaran walaupun pembelajaran secara daring, misalnya dengan memanfaatkan media online, seperti google meet.

Untuk mengatasi berbagai kendala dan permasalahan di atas, kami mendukung upaya Pemerintah yang selalu mengupayakan dan mencari solusi agar kegiatan pembelajaran dapat berlangsung dengan baik selama pandemi, yaitu dengan melakukan kegiatan pengabdian pada masyarakat, tepatnya pada siswa 
Sekolah Dasar, dengan memadukan pembelajaran daring dengan tatap muka yang disebut dengan Blended Learning model flipped classroom. Kegiatan pengabdian pada masyarakat dilakukan melalui tatap muka dengan protokol kesehatan yang ketat. Kegiatan ini mendapat sambutan hangat dari Kepala Sekolah dan Bapak Ibu Guru baik di SD Negeri Margosari, SD Negeri Jurang Jero, maupun SD Negeri Kalipetir 3. Berikut langkah-langkah kegiatan pengabdian pada masyarakat yang telah dilaksanakan:

\section{Persiapan Kegiatan}

Mengidentifikasi pelaksanaan kegiatan pembelajaran guru di kelas selama pandemi (apakah materi pembelajaran sudah tersampaikan, menggunakan media apa dalam menyampaikan, bagaimanakah cara penyampaian pembelajaran selama pandemi, apakah ada konfirmasi/ refleksi di setiap pembelajaran. Untuk pelaksanaan PPM sudah mendapatkan ijin dari Bapak Ibu Kepala Sekolah dengan melibatkan mahasiswa IKIP PGRI Wates, pelaksanaan tertib patuh terhadap protokol COVID-19.

\section{Pelaksanaan Kegiatan}

\section{a. Kegiatan Ceramah}

Kegiatan ceramah ini dilakukan untuk menyampaikan materi tentang ruang lingkup pembelajaran daring/ online, blended learning, karakteristik Flipped classroom. Blanded learning dengan model flipped classroom dapat mengaktifkan peserta didik dalam pembelajaran meskipun secara daring (online), Muzyka \& Luker (2016: 3). Pelaksanaan kegiatan ini masih dilakukan di ruangan pertemuan dengan protokol ketat COVID-19.

\section{b. Kegiatan Tanya Jawab}

Tanya jawab dilakukan setelah kegiatan ceramah selesai. Pertanyaanpertanyaan disampaikan oleh Bapak Ibu Guru SD Negeri Margosari, SD Negeri Jurangjero, dan SD Negeri Kalipetir 3.

\section{c. Kegiatan Latihan dan Diskusi}

Kegiatan latihan ini dilaksanakan setelah dilaksanakan diskusi dan proses tanya jawab, pada tahap ini guru kelas berkolaborasi dengan mahasiswa mahasiswi PGSD. Jadwal pelaksanaan latihan di setiap SD berbeda beda, sudah dikonsultasikan kepada pihak sekolah. Pada pertemuan pertama yaitu 
guru bersama mahasiswa mahasiswi diberi tugas untuk mendesain dan mengembangkan pembelajaran dengan blended learning model flipped calssroom. Pada pertemuan kedua mempresentasikan hasil pengembangan pembelajaran, baik materi pembelajaran maupun video pembelajaran. Pertemuan 3 diisi dengan praktek pembelajaran secara online dengan blended learning model flipped calssroom di kelas. Kegiatan ini memanfaatkan media Whatsap untuk pembukaan pembelajaran, share materi ataupun video pembelajaran, dan google meet untuk merefleksi pembelajaran. Setelah kegiatan latihan, maka bapak ibu guru bersama mahasiswa saling berkolaborasi untuk mengelola kelas.

\section{Evaluasi Kegiatan}

Terlaksananya program pendampingan belajar dengan blended learning model flipped classroom di SD Negeri Margosari, SD Negeri Jurangjero, dan SD Negeri Kalipetir 3 menjadi salah satu solusi untuk mengatasi kekurangan/ kendala pembelajaran secara online. Peserta didik dan orangtua terbantu dan memberikan respon positif terhadap kegiatan pendampingan belajar di kelas. Adanya refleksi pembelajaran secara lisan dengan media google meet mempunyai manfaat yang besar bagi peserta didik, antara lain : membantu peserta didik untuk lebih memahami materi pembelajaran (tidak hanya penugasan), memperkecil salah konsep dalam memahami materi pembelajaran yang disampaikan secara online, pendidik bisa melihat sampai sejauh mana kemampuan peserta didik dalam memahami materi pembelajaran yang dilaksanakan secara online, dan dapat dijadikan sebagai pandangan oleh pendidik bagaimana mengimplementasikan dan menyampaikan materi pembelajaran yang baik agar mudah diterima oleh peserta didik selama masa pandemi.

Kegiatan PPM ini dapat terlaksana dengan baik dan lancar karena kuatnya faktor pendukung. Masa Pandemi bukan berarti menghalangi dan mengurangi semangat dan antusias Bapak Ibu Guru dalam mengikuti kegiatan PPM. Setiap metode yang disampaikan oleh pemateri berjalan dengan baik. Bapak Ibu Guru antusias mengikuti kegiatan ini, terlihat tidak ada yg absen ketika pelaksanaan, keaktifan Bapak Ibu Guru terlihat juga dalam sesi tanya jawab serta pada saat 
pelatihan dan pendampingan Blended Learning di kelas. Harapan kami dengan adanya kegiatan PPM ini diharapkan Bapak Ibu Guru dapat menerapkan Blended Learning di setiap pembelajaran sebagai upaya mengatasi permasalahan di masa pandemi.

\section{KESIMPULAN}

Pandemi Covid 19 menyebabkan lumpuhnya kegiatan dan aktivitas manusia, termasuk di bidang pendidikan. Pendidikan yang semula berjalan secara tatap muka pelaksanaannya berubah menjadi pembelajaran yang dilaksanakan secara daring dikarenakan pembelajaran tidak memungkinkan jika dilaksanakan secara tatap muka. Namun selama daring ditemukan beberapa kelemahan dan kendala pada saat proses pembelajaran. Kemandirian belajar di rumah selama daring menjadikan pembelajaran berpusat pada peserta didik (student centered), sedangkan untuk anak Sekolah Dasar tentunya tetap membutuhkan suatu pendampingan dalam belajar. Untuk itu salah satu solusi yang dapat dipilih untuk mengatasi permasalahan dalam pembelajaran selama pandemi yaitu mengemas pembelajaran dengan blended learning dengan model flipped classroom, dimana model ini memadukan antara pembelajaran daring dengan pembelajaran tatap muka namun tetap menciptakan pembelajaran yang aktif. Model ini dinilai lebih efektif daripada model pembelajaran daring, sebab peserta didik tidak hanya dihadapkan dengan tugas-tugas yang diberikan oleh guru tanpa adanya konfirmasi/ penjelasan di akhir pembelajaran.

\section{DAFTAR PUSTAKA}

Bergmann, J., \& Samsa , A. (2012). Flipped Your Classroom: Reach Every Student In Every Class Every Day. USA: ISTE

Brent, J.G. (2013). Student Perceptions Of The Flipped Classroom. Columbia: The University Of British Columbia.

Bonk, C.J., \& Graham, C.R. (2006). The Handbook of Blended learning. USA: Pfeiffer

Chaeruman, U. (2017). Pedati Model Desain Sistem Pembelajaran Blended. Jakarta: Ristekdikti. 
Driscoll, M. (2002). Blended Learning: Let's Get beyond the Hype. IBM Global Services.

Dziuban, dkk. (2018). Blended Learning: The New Normal and Emerging Technologies. International Journal of Educational Technology in Higher Education, Volume 15 Nomer 3, Hal: 1-16.

Handarini, O.I., \& Wulandari, S.S. (2020). Pembelajaran Daring Sebagai Upaya Study From Home (SFH) Selama Pandemi Covid 19. Jurnal Pendidikan Administrasi Perkantoran (JPAP), Volume 8 Nomer 3, Hal : 496 - 503.

Husamah. (2014). Pembelajaran Bauran (Blended Learning) Terampil Memadukan Keunggulan Pembelajaran Face-To-Face, E-learning OfflineOnline, dan Mobile Learning. Jakarta: Prestasi Pustaka.

Kalantarrashidi, dkk. (2015). Effect of Blended Learning Classroon Environment on Student's Satisfaction. Journal of Educaion and Training Studies, Volume 3 Nomer 5, Hal : $225-230$.

Muzyka J.L., \& C.S. Luker (2016). The Flipped Classroom Volume 1: Background and Challenges ACS Symposium Series. American Chemical Society: Washington, DC.

Saunders, M.J. (2014). The Flipped Classroom: Its Effects on Student Academic Achievement, and Critical Thinking Skills in Mathematics in High Schools. Liberty University.

Steele, K. M. (2013). The Flipped Classroom: Cutting-Edge, Practical Stategies To Successfully "Flip" Your Classroom. Online.

Sukarno. (2011). Blended Learning Sebuah Alternatif Model Pembelajaran Mahasiswa Program Sarjana (S1) Kependidikan Bagi Guru dalam Jabatan. Jurnal Didaktika Dwija Indria, Volume 1 No 2, Hal: 1 - 11.

Oktaria, S.D., dkk. (2018). Model Blended Learning. Banjarwangi : Ganjar Tanam.

Wardani, D.N., Toenlio, A.J.E., \& Wedi, A. (2018). Daya Tarik Pembelajaran Di Era 21 Dengan Blended Learning. Jurnal Kajian Teknologi Pendidikan, Volume 1 Nomer 1, Hal: 13 -18.

Widiara, I.K. (2018). Blended Learning Sebagai Alternatif Pembelajaran Di Era Digital. Jurnal Agama dan Budaya, Volume 2 Nomer 2, Hal: 50 - 56.

Yulietri, F., \& Mulyoto, M. (2015). Model Flipped Classroom dan Discovery Learning Pengaruhnya terhadap Prestasi Belajar Matematika Ditinjau dari Kemandirian Belajar. Jurnal Teknodika, Vol 13 No 2, Hal 1 - 17. 